\title{
The Politics of Comparison: Connecting Cultures Outside of and in Spite of the West
}

\author{
Barbara A. Holdrege
}

Wilhelm Halbfass, in his landmark study India and Europe (1988), explores the history of intellectual encounters between India and Europe from classical antiquity to the twentieth century. He concludes his study with a discussion of the "global predicament of Westernization" in the contemporary period, reflecting more specifically on the problems that the so-called "Europeanization of the earth" presents for both European and Indian partners in the "dialogue."

Will the "Europeanization" of the earth be reversed? Are other cultures and traditions...ready to provide alternatives? In the modern planetary situation, Eastern and Western "cultures"...meet in a Westernized world, under conditions shaped by Western ways of thinking. The medium, the framework of any "dialogue" seems to be an irreducibly Western one. But is this factually inescapable "universality" the true telos of mankind? Could it be that the global openness of modernity is still a parochially Western, European horizon (440)? ${ }^{1}$

Halbfass's question concerning the European-and more broadly, European-American-presumption that history's direction is towards a modern, open, universal, and essentially "Western" global culture has been thrown into sharp relief by the events since $9 / 11$ on the world's stage here and abroad. At a minimum, we can certainly say that all the players in this global drama of cultural and ideological conflict do not

International Journal of Hindu Studies 14, 2-3 (2010): 147-75

(C) The Author(s) 2011. This article is published with open access at Springerlink.com

DOI 10.1007/s11407-011-9090-y 
share the same perspective on this important question. In this essay I will explore the critical necessity of going beyond the "parochially Western, European horizon" of the "dialogue" among the world's cultures and undertaking an alternative form of cross-cultural encounter in which Europe is not the privileged partner. Indeed, what if we were to remove Europe as a principal partner in the encounter and to investigate instead India's connections with other cultures whose distinctive histories have unfolded outside of, inside of, and in spite of the West? What if we were to shift the focus of our comparative studies in the academy from "India and Europe" to "South Asia and the Middle East" and to explore the ongoing economic, political, social, cultural, and religious connections that linked these two regions long before the "Europeanization of the earth"? I would suggest that this type of comparative enterprise can serve as an important antidote to the epistemological hegemony of "Europeanization"-and its more recent counterpart, "Americanization"-by providing a multiplicity of different imaginaries that do not privilege "Western" idioms associated with the modernist project but are rather grounded in the indigenous idioms of the cultures of South Asia and the Middle East.

My own work as a comparative historian of religions has emphasized the role of comparative study as an inextricable component of the scholarly enterprise and as a method of critical interrogation that can serve as a means to dismantle the tyranny of prevailing paradigms and to explore a range of alternative epistemologies. I have been concerned in particular with two functions of comparative analysis: first, as a heuristic tool through which we construct and apply our scholarly categories and models; and, second, as a critical method through which we continue to test, reassess, refine, deconstruct, and reconstitute these categories and models (see Holdrege 2000). ${ }^{2}$

In the academic study of religion, as in other disciplines, we use a variety of categories to select, analyze, classify, and interpret phenomena. Analytical categories such as symbol, myth, ritual, scripture, law, ethics, and mysticism have historically assumed a central role in the discourse of religious studies. Comparative analysis is intrinsic to the process through which we construct and apply such categories. We use categories as instruments of inclusion and exclusion by means of which we classify religious phenomena according to whether they share or do not share 
certain properties. For example, we construct and define the category "scripture" and then we survey and compare a range of potential candidates - the Hebrew Bible, the Vedic Saṃhitās, the Qurān, the I Ching, and so on-to determine in each case whether the indigenous categories accord with our scholarly constructions of the category "scripture."

The process of comparison involved in the formation and application of categories is inherently evaluative and hierarchical in that it establishes a standard against which particular phenomena are judged for inclusion or exclusion and are ranked as marked or unmarked taxa. The "politics of comparison" has been emphasized by Paul Morris (1992):

[The process of comparison] compares two or more things against the standard of one thing, producing a hierarchical scale....First, one cannot compare two or more things without first constructing a heuristic scale or scales, consisting of one or more comparators, that allows one to identify the two things as comparable in terms of some given category. Secondly, the choice of scale is a "political" decision in that the given comparator is inherently evaluative.

The politics of comparison in religious studies and other disciplines in the human sciences extends beyond the construction of particular categories to the development of encompassing taxonomies, or classificatory systems, constituted by these categories and their interrelations. These classificatory schemas at times serve as models in the discourses of various disciplines. These models are themselves inherently hierarchical, establishing evaluative scales according to which their constitutive categories are positioned and ranked in relation to one another. The hierarchy of taxonomies becomes the "tyranny of taxonomies" when certain models are accorded a privileged status as governing paradigms, while competing theories and models are marginalized.

In the following analysis I will explore how this tyranny of taxonomies is exemplified in two related sets of paradigms that have assumed the status of dominant discourses in the human sciences in Europe and North America since the nineteenth century as part of the process of the "Europeanization of the earth": the Eurocentric paradigms that have dominated scholarship in the social sciences and humanities, including history, 
anthropology, sociology, political science, economics, geography, psychology, philosophy, religious studies, and literary studies; and the Protestant Christian paradigms that have dominated scholarship in religious studies more specifically. One of the important tasks of comparative study in this context is to challenge scholars to become critically self-conscious of the legacy of these dominant paradigms that lingers in our categories and taxonomies and to reconfigure our scholarly discourses to include a multiplicity of epistemic perspectives. In the first section of my analysis, I will argue that comparative studies of South Asia and the Middle East can provide the basis for developing alternative epistemologies to the Eurocentric paradigms that have dominated scholarship in the human sciences. In the second section, I will suggest that comparative studies of Hindu and Jewish traditions-religious traditions rooted in South Asia and the Middle East, respectively-can provide the basis for developing alternative epistemologies to the Protestant-based paradigms that have dominated the academic study of religion.

\section{South Asia and the Middle East: Beyond European Hegemony}

Eurocentrism has its counterpart in orientalism and Christian missionizing projects, in which "Europe" or "the West" provides the implicit standard against which the "Rest of the World" and the "Rest of the Religions" are compared and evaluated. Thus, Western studies of South Asia and the Middle East have generally been undertaken, explicitly or implicitly, within a comparative framework in which European conceptual categories provide the standard of comparison. This "European epistemological hegemony" ${ }^{4}$ has served to legitimate and perpetuate colonial and neo-colonial projects. Long after the period of decolonization, the "post-colonial predicament" of scholars in the human sciences has involved coming to terms with the legacy of this hegemonic discourse, which still prevails as an "internal Eurocentrism" and "internal orientalism" that operate-albeit unconsciously-in the representational strategies, categories, and practices of many scholars (see Breckenridge and van der Veer 1993). Following the seminal critiques of Eurocentric ideology in Edward Said's Orientalism (1978) and Samir Amin's Eurocentrism (1989), scholarship in the areas of world economic and 
social history and world-system analysis has challenged the dominant discourse of Eurocentrism on two fronts: first, through sustained critiques of prevailing social, economic, and geographic theories and the Eurocentric historiographies on which they are based; and, second, through extended analyses of the contributions of the "Rest of the World"- and in particular Asia and the Middle East-to the world-system before, during, and after the "European hegemony" that characterizes the modern period. $^{5}$

J. M. Blaut's work is representative of the first trend of scholarship. ${ }^{6}$ In his The Colonizer's Model of the World: Geographical Diffusionism and Eurocentric History (1993), he argues that Eurocentrism-and more specifically the world model of European diffusionism founded on the theory of "the European miracle"7 — provided the "colonizer's model of the world" that served to explain, legitimate, and promote colonial and neo-colonial projects. Despite the emergence of post-colonial studies and other forms of ideological criticism that have challenged Eurocentric and orientalist ideologies from various disciplinary perspectives, Blaut maintains that the pervasive and enduring legacy of Eurocentrism still persists in the academy in the form of unconsciously perpetuated axiomatic propositions that are ascribed the status of "facts."

There is... a problem with the word "Eurocentrism." In most discourse it is thought of as a sort of prejudice, an "attitude," and therefore something that can be eliminated from enlightened thought....But the really crucial part of Eurocentrism is not a matter of attitudes in the sense of values and prejudices, but rather a matter of science, and scholarship, and informed and expert opinion. To be precise, Eurocentrism includes a set of beliefs that are statements about empirical reality, statements educated and usually unprejudiced Europeans accept as true, as propositions supported by "the facts."...If they [historians] assert that Europeans invented democracy, science, feudalism, capitalism, the modern nation-state, and so on, they make these assertions because they think that all of this is fact.... How is it that Eurocentric historical statements which are not valid-that is, not confirmed by evidence and sometimes contradicted by evidence-are able to gain acceptance in European historical thought, and thereafter survive as accepted beliefs, hardly questioned, for generations and 
even centuries? This is a crucial problem for historiography and the history of ideas (9). ${ }^{8}$

The world model of European diffusionism, according to Blaut, posits that the world has an "Inside" and an "Outside," a permanent center and a permanent periphery, and that significant cultural innovations have generally originated in the center-"Greater Europe," including the continent of Europe and countries of European settlement overseas-and have flowed from the center via diffusion to the periphery- "non-Europe," including Asia, Africa, and Latin America. This Eurocentric paradigm, as characterized by Blaut in both its classical and modern formulations, posits a series of hierarchical dichotomies between socio-cultural categories that distinguish "Europe" from "nonEurope" (8-43).

\section{Eurocentric Paradigm: \\ Hierarchical Dichotomies 9}

Europe
rationality
abstract thought
mind
spirit
modernity
progress
inventiveness
freedom
individualism

Non-Europe
irrationality
concrete thought
body
matter
tradition
stagnation
imitativeness
despotism
community

Blaut provides an extensive critique of scholarly theories of the autonomous "rise of the West" — or the myth of "the European miracle"that have sustained European epistemological hegemony in the academy. He defines this myth as "the argument that Europe forged ahead of all other civilizations far back in history-in prehistoric or ancient or medieval times - and that this internally generated historical superiority or priority explains world history and geography after 1492: the modernization of Europe, the rise of capitalism, the conquest of the world" (50). 
Blaut systematically examines and refutes the various types of arguments that have been used to support the theory of "the European miracle," including biological arguments concerning the racial superiority and demographic uniqueness of the Europeans; environmental arguments concerning the superior qualities of Europe's temperate environment over the tropical conditions of Africa and the arid conditions of Asia; and cultural arguments concerning the superior nature of European rationality, technology, and social structures (59-135).

While the major portion of Blaut's study is devoted to critiquing theories that support the myth of European exceptionalism, in the second phase of his study he provides a brief comparative historical analysis of the medieval landscapes of Europe, Asia, and Africa in order to show that Europe was not more advanced or more progressive than other civilizations prior to 1492. Rather, protocapitalist centers were developing in all three continents and formed a single commercial network that interconnected Western Europe, the Mediterranean, East Africa, the Middle East, South Asia, Southeast Asia, and East Asia (152-78). Europe's only advantage was its geographic location, which after 1492 allowed the Europeans to take the lead because of the wealth and power they accrued through colonial accumulation in America and later in Asia and Africa (179-213). Blaut concludes:

There was no "European miracle." Africa, Asia, and Europe shared equally in the rise of capitalism prior to 1492. After that date, Europe took the lead. This happened...because of Europe's location near America and because of the immense wealth obtained by Europeans in America and later in Asia and Africa-not because Europeans were brighter or bolder or better than non-Europeans, or more modern, more advanced, more progressive, more rational. These are myths of Eurocentric diffusionism and are best forgotten (206).

Although Blaut's methodology and analytical categories are problematic in certain ways, ${ }^{11}$ his work is nevertheless representative of an important trend of scholarship that attempts to debunk the myth of European exceptionalism from the perspective of world history and world-system analysis by demonstrating that prior to the modern period Europe enjoyed no special advantage but, on the contrary, played a 
peripheral role in a world-system that was dominated by Asia and the Middle East. Advocates of such an approach generally take as their starting-point a critique of Immanual Wallerstein's The Modern WorldSystem (1974-89). Wallerstein's Eurocentric theory of the "modern world-system" argues that after 1450 a world economy emerged that was centered in Europe, which constituted the "core" from which the system expanded to incorporate the "Rest of the World" as "semi-periphery" or "periphery." Wallerstein's theory has been challenged from a variety of perspectives, particularly with respect to, first, his treatment of the modern world-system as the first and only world-system; second, his over-privileging of the role of Europe in the development of the modern world economy; and, third, his corresponding neglect of the role of Asia and the Middle East in the formation of the modern world-system.

Janet Abu-Lughod, in Before European Hegemony: The World System A.D. 1250-1350 (1989), provides an important corrective to Wallerstein's theory by demonstrating that the modern world-system has a precursor in an earlier thirteenth-century world-system. In contrast to Wallerstein's characterization of the modern world-system as organized hierarchically around a single center, Abu-Lughod maintains that the thirteenth-century world-system was organized on fundamentally different principles and consisted of multiple centers that were integrated in a single economic system (364-65). She provides an extended comparative historical analysis of the eight interconnected subsystems that linked Europe, the Middle East, and Asia in a single network of coexisting core powers. ${ }^{12}$ Contrary to the myth of European exceptionalism, Abu-Lughod argues that in this world-system Europe was "an upstart peripheral to an ongoing operation" and that the "rise of the West" cannot be explained with reference to "the special technological, cultural, psychological, or even economic characteristics of European society" $(12,353)$.

In terms of time, the century between A.D. 1250 and 1350 constituted a fulcrum or critical "turning point" in world history, and in terms of space, the Middle East heartland region, linking the eastern Mediterranean with the Indian Ocean, constituted a geographic fulcrum on which West and East were then roughly balanced. The thesis of this book is that there was no inherent historical necessity that shifted the system to favor the West rather than the East, nor was there any inherent historical 
necessity that would have prevented cultures in the eastern region from becoming the progenitors of a modern world system (12).

Abu-Lughod maintains that the "rise of the West" in the sixteenth century can best be explained in terms of a number of important systemic changes in the fourteenth century-geographic, political, and demographic - that disrupted the world-system and precipitated the "fall of the East," which left a vacuum of power that was subsequently filled by a succession of previously unimportant European players - the Portuguese, the Spanish, the Dutch, and the British (18-20, 359-64).

Marshall Hodgson, in his posthumously published collection of essays Rethinking World History: Essays on Europe, Islam, and World History (1993), similarly argues against privileging Eurocentric paradigms of world history and world geography and seeks to situate the "rise of the West" in the broader context of a multinodal "Afro-Eurasian" network comprising four core regions: Europe, the Middle East, India, and China. Surveying the "interregional configuration of historical relationships" in this Afro-Eurasian network since the second millennium B.C.E., he notes that Western Europe played a peripheral role as a frontier region until the end of the Middle Ages and that-far from being a pivotal cultural innovator-Western Europe was the beneficiary of a one-sided flow of cultural exchange that proceeded from East to West: from China, India, the Middle East, and the eastern Mediterranean to Western Europe (1928). It was this flow of cultural innovations from the broader AfroEurasian network that provided the basis for "the great Western Transmutation" in the period between 1600 and 1800 .

The great modern cultural Transmutation presupposed numerous inventions and discoveries originating in all the several citied peoples of the Eastern Hemisphere,...not... in Europe. In particular, most of the more immediately formative elements that led to the Transmutation, both material and moral, had come to the Occident, earlier or later, from other regions.... At least as important was the very existence of the vast world market, constituted by the Afro-Eurasian commercial network, which had cumulatively come into being, largely under Muslim auspices, by the middle of the second millennium....Without the cumulative history of the whole Afro-Eurasian Oikoumene, of 
which the Occident had been an integral part, the Western Transmutation would be almost unthinkable (67-68).

Among recent critics of Eurocentrism from the perspective of worldsystem analysis, Andre Gunder Frank is one of the most vigorous exponents of the need to "reOrient" and reassess the contributions of the "Rest of the World" to the shared histories of humankind before, during, and after European hegemony. While applauding the efforts of Amin, Blaut, Abu-Lughod, Hodgson, and other critics of European exceptionalism, Frank argues that none of these critiques is sufficient to uproot the epistemological legacy of Eurocentric ideology. In his ReOrient: Global Economy in the Asian Age (1998), he challenges in particular the prevailing assumption-held by many historians and social theorists of Europe as well as world-system theorists- that there was a fundamental discontinuity in world history, generally dated around 1500, that distinguishes the medieval period from the modern period, in which the world was radically transformed by the "rise of the West" and the development of capitalism (see especially 328-29, 342-44). In this context he refutes Abu-Lughod's contention that the thirteenth-century world-system was a different world-system, organized on fundamentally different principles, from the modern world-system described by Wallerstein as emerging in 1450. He argues that the modern world-system is rather a continuation of Abu-Lughod's thirteenth-century system and, moreover, that this thirteenth-century world-system is a continuation of a much older system (xix, xxi-xxii). ${ }^{13}$

Frank provides a global comparative analysis of early modern world economic history between 1400 and 1800 in which he attempts to show that, contrary to Wallerstein's portrayal of a European-centered modern world-system, during this period the world-system did not have a single center but rather was characterized by multiple centers, in which China, India, and West Asia, or the Middle East, assumed pivotal roles. Moreover, while the "rise of the West" is generally dated prior to 1800 by theorists such as Blaut (after 1492), Abu-Lughod (sixteenth century), and Hodgson (between 1600 and 1800), Frank argues that Europe did not assume a dominant position in the world economy until after 1800 .

The very search for "hegemony" in the early modern world economy 
or system is misplaced. Europe was certainly not central to the world economy before 1800. Europe was not hegemonic structurally, nor functionally, nor in terms of economic weight, or of production, technology or productivity, nor in per capita consumption, nor in any way in its development of allegedly more "advanced" "capitalist" institutions. In no way were sixteenth-century Portugal, the seventeenth-century Netherlands, or eighteenth-century Britain "hegemonic" in world economic terms. Nor in political terms....In all these respects, the economies of Asia were far more "advanced," and its Chinese Ming/Qing, Indian Mughal, and even Persian Safavid and Turkish Ottoman empires carried much greater political and even military weight than any or all of Europe (5).

Frank argues further that the rise of Europe to a dominant position in the world economy after 1800 cannot be explained with reference to "any kind of European 'exceptionalism' of rationality, institutions, entrepeneurship, technology, geniality, in a word —of race" (4) but rather must be understood in conjunction with the "decline of the East" in the late eighteenth century. Building on Blaut's thesis, he maintains that the European states used silver and gold extracted from the American colonies to buy their way into a flourishing Asian market and then, having "bought themselves a seat, and then even a whole railway car, on the Asian train" (277), they took advantage of the subsequent decline of the economies of India, West Asia, and China and built a new "hegemonic" order centered in Europe (258-320).

Frank calls for a radical re-visioning of the dominant social and economic theories, models, and categories that have served to perpetuate the legacy of Eurocentrism in the academy, including theories of European exceptionalism and corresponding models of the "rise of the West," theories of a distinctive "Asiatic mode of production," constructions of "capitalism" and "feudalism," and notions of European "hegemony" (321-39). "The only solution," he suggests, "is to cut the Gordian knot altogether and divest ourselves of all these useless Eurocentric categories, which only lead to arcane debates and blind us to the real historical process....They were all derived only from European/Western ethnocentrism, which was propagated around the world-West and East, North and South - as part and parcel of Western colonialism and cultural impe- 
rialism" (336). As an alternative to Eurocentric paradigms, Frank emphasizes the need for social theories that are based on a "globally holistic world systemic perspective" (341). In contrast to area studies, which tend to foster parochialism by focusing on one region of the world to the exclusion of others, such a global approach is concerned with understanding how each of the world's cultures-in the Americas, Europe, Africa, Asia, and Australasia-is shaped by the dynamic network of economic, political, social, and cultural exchanges that constitutes the world-system (see especially 340-41, 344).

While Blaut, Abu-Lughod, Hodgson, and Frank may diverge in their explanations of when and why the "rise of the West" occurred, their scholarly projects converge in challenging the dominant discourses and the myth of European exceptionalism that sustains them. This review of their scholarship brings us back to a consideration of the role of comparative analysis as an inextricable component of our scholarly methods. I would like to examine briefly three aspects of the role of comparison that are brought to light by these critiques of European epistemological hegemony.

First, the politics of comparison is evident in the mechanisms through which Eurocentric paradigms-along with the missionizing and racialization projects they have fostered-have persisted in the academy and served as instruments of inclusion and exclusion. These paradigms have perpetuated hierarchical taxonomies that privilege certain categoriessuch as rationality, modernity, progress, capitalism, freedom, and individualism - that together constitute the ideal type "European." Such taxonomies provide an explicit or implicit comparative framework against which the "non-European" Other is judged and excluded by a series of absences-as non-rational, non-modern, non-progressive, noncapitalist, and so on. European social, cultural, political, economic, and geographic categories are deemed to be paradigmatic and thus provide the implicit standard against which the non-conforming categories or features of other cultures are evaluated in terms of an absence and judged as aberrant, exotic, or deficient by virtue of their non-compliance with the standard.

Second, comparative analysis can serve as a critical method to dismantle the tyranny of Eurocentric taxonomies, as illustrated by the studies of Blaut, Abu-Lughod, Hodgson, and Frank. Through comparative historical 
analyses of the economic, political, and socio-cultural institutions of Europe and the "Rest of the World" at various points in history, these scholars have shown that prior to the modern period-whether dated from 1500 or 1800 -Europe was not exceptional at all but, on the contrary, played a peripheral role in a world-system that was dominated by Asia and the Middle East. In this context comparative analysis serves as a method of critical interrogation that challenges scholars to reassess and re-vision the prevailing categories, models, and theories that have fostered the myth of European exceptionalism in the academy. The hierarchical model of a world-system with a single center is de-centered and displaced by an alternative model: a world-system constituted by a synergistic multinodal network of economic, social, and cultural exchanges.

Third, the role of comparative analysis as a method of critical interrogation includes not only deconstructing the prevailing paradigms but also constructing a multiplicity of alternative imaginaries. This type of analysis involves an epistemic shift from a focus on white-male-EuropeanProtestant-Christian dominants as the default cultural template to an exploration of the systems of knowledge, forms of expressivity, and cultural practices of peoples and cultures that have been relegated to the margins by the dominant discourses. The post-colonial theorist Walter Mignolo has suggested that we need to explore the possibilities of new forms of knowledge, which he calls "border thinking," and "to "think otherwise,' from the interior exteriority of the border...[in order] to move beyond the categories created and imposed by Western epistemology." "The political and the ethical are at this point in need of a new epistemology, epistemologies that come from the borders and from the perspective of subaltern coloniality."14

One possible approach to generating new epistemologies, suggested by the work of Frank and other world-system theorists as well as global studies advocates, is to adopt a global perspective and to develop new categories and models through a comparative macrohistory of the contributions of the key players in the world-system in various historical periods. A global studies approach provides an attractive alternative to the traditional area studies approach, with its orientalist legacy and historical roots in cold war strategic concerns. However, most of the critics of Eurocentrism and orientalism who have adopted a world- 
system perspective have ironically still tended to allot Europe a privileged role in their studies by giving undue attention to it as the hegemonic upstart whose claims to exceptionalism must be subverted through comparison with other cultures' contributions to the worldsystem.

In my own work I have pursued an approach that can serve to mediate between a global studies approach and the traditional area studies approach. This approach, rather than attempting to compare the contributions of all the nodes in the multinodal world-system, entails a more circumscribed comparative study focused on two of the nodes, two of the key players, in the world-system before, during, and after European hegemony: South Asia and the Middle East. Moreover, rather than viewing South Asia and the Middle East from the perspective of these regions' pre-colonial, colonial, and post-colonial encounters with Europe, this comparative approach removes the European optic and gives priority instead to studying the historical connections and structural affinities between the cultures of South Asia and the Middle East directly, without privileging Europe as an explicit or implicit partner in the comparison.

Comparative studies of the cultures of South Asia and the Middle East-including a consideration of economic, political, social, cultural, and religious connections - contribute to our scholarly discourse in the human sciences by generating a rich array of new categories and models that are grounded in the distinctive idioms of cultures that shared complexly interwoven histories long before the "rise of the West." Recent initiatives in this area include the Middle East and South Asia Comparative Studies Project at the University of California, Santa Barbara, inaugurated in 2001, and the forthcoming Encyclopedia of the Middle East and South Asia, edited by Gordon Newby. My colleague Dwight Reynolds remarks concerning the significance of such comparative studies:

Western scholarship on the Middle East and South Asia has been dominated almost entirely by discussions of the bilateral relationship of each of these regions to the West while ignoring questions about their relationship to each other....The emergence of critical schools of thought such as subaltern studies, postcolonial studies, and the overall critique of orientalism, have all attempted to rectify this dominant 
view, but even these schools of thought have generally restricted their focus to critiquing the "vertical" or "center-periphery" relationship between colonized and colonizers. They have for the most part ignored the potential for radically resituating that discourse through scrutiny of the "lateral" relationships that obtain among regions of the globe without triangulating that inquiry through Europe....There is a complex web of multifaceted historical connections linking these two regions [the Middle East and South Asia] that remains virtually ignored in western scholarship due to the overriding interest in studying how each of these regions has interacted with the West. To study the Middle East and South Asia without constant reference to the West is thus not only to study these regions from a perspective much closer to their own historical worldview, but also to explore territory almost untouched by western scholarship (Reynolds 2001).

Abu-Lughod, as the keynote speaker at the inaugural symposium of the UCSB Middle East and South Asia project in March 2001, emphasized the need for sustained comparative studies of the long-standing economic, socio-cultural, and religious connections between the Middle East and South Asia. While recognizing the potential contributions of such comparative studies in "de-center[ing] both traditional area studies and the ostensibly new field of globalization studies," she also emphasized the importance of undertaking such studies within the broader context of world-system analysis in order to understand how the relations between the Middle East and South Asia have been affected by the changing dynamics of the world-system in different historical periods.

The persistent connections between the Middle East and Asia cannot be overemphasized. Anyone with a deeper historical perspective would take these connections as an assumed "fact," since the existence of mini-world-systems, prior to the achievement of "western" dominance over both regions during the colonial period, is hardly a problematic to be explained.... History is written by the victor, [and therefore] for too long not only the world, but the description of it has been shaped by the dominant. This has led not only to distortions, but to a sad neglect of the study of ongoing connections between the Middle East and Asia....[But] a myopic focus on even this vastly extended "area studies" 
model would be inadequate.... Regional area studies and processes of globalization are not mutually exclusive enterprises. At various points in time, the intra-regional relations [between the Middle East and Asia] have been affected by the larger (and changing) characteristics of global forces. A truly exemplary program will want to address how Middle Eastern-Asian connections have been shaped and transformed by globalization, early, late, and present (Abu-Lughod 2001).

\section{Hinduisms and Judaisms: Beyond Protestant Christian Hegemony}

My own work as a comparative historian of religions has focused on an exploration of the affinities between two religious traditions that are rooted in South Asia and the Middle East: Hinduisms and Judaisms. The differences between Hindu and Jewish traditions have often been emphasized, so much so that these traditions have generally been characterized as representing opposite ends of the spectrum of the world's religions. However, in recent years such characterizations have been challenged from a variety of perspectives, and there has been an upsurge of interest in the comparative study of Hindu and Jewish traditions among scholars of religion. The 1994 collection of essays edited by Hananya Goodman, Between Jerusalem and Benares: Comparative Studies in Judaism and Hinduism, represents one of the first serious efforts by a group of scholars of Judaica and South Asia to explore the historical connections and cross-cultural resonances between these traditions. ${ }^{15}$ A number of forums have been established to foster comparative studies of Hindu and Jewish traditions and, more broadly, of Indic and Jewish cultures: the Society for Indo-Judaic Studies (1993); the Journal of Indo-Judaic Studies (1994); the American Academy of Religion Comparative Studies in Hinduisms and Judaisms Consultation (1995); and the American Academy of Religion Comparative Studies in Hinduisms and Judaisms Group (1998). More recently, an international conference convened at Oxford University inspired the volume of essays Indo-Judaic Studies in the Twenty-First Century (Katz et al. 2007). ${ }^{16}$ The volume advances the emerging field of "Indo-Judaic studies" in significant ways by providing the first sustained multidisciplinary investigation of the social, political, economic, cultural, and religious connections between Indic and Jewish cultures from ancient to contemporary times. 
What does an exploration of the intersections of Indic and Judaic cultures contribute to the broader scholarly enterprise of religious studies and the human sciences more generally? I would argue that such comparative inquiries - and more specifically, comparative studies of Hindu and Jewish traditions undertaken within a religious studies frameworkcan play an important role in dismantling European epistemological hegemony by providing alternative epistemologies to the Protestantbased paradigms that have served to perpetuate the ideals of Enlightenment discourse and colonialist projects.

These paradigms originated from a predominantly Protestant Christian academic elite in the European academy in the nineteenth century. The continuing epistemological and institutional hegemony of Christian traditions in the academic study of religion in Europe and North America is clearly discernible in the structure of the American Academy of Religion (AAR). As of April 2010, out of the seventy-seven AAR Program Units that were devoted to the study of particular religious traditions, thirty-three, or forty-three percent, were allotted to the study of Christian traditions. Moreover, sixteen of these Program Units were focused primarily on some aspect of Christian theology, while there were only two Program Units that included consideration of the theology of non-Christian traditions. Furthermore, only two Program Units were devoted exclusively to Hindu traditions and one to Jewish traditions, along with three additional Program Units that included one or both of these traditions in their purview. ${ }^{17}$ The institutional structure of the AAR thus accords a privileged status to Christian traditions, not only as the object of historical studies but also as the focus of sustained theological reflection.

The Christian - and more specifically Protestant-legacy of the academic study of religion is evident in the way in which the prevailing paradigms of religious tradition tend to privilege certain categories while marginalizing others. These paradigms emphasize a series of hierarchical dichotomies in which categories that accord with the Protestant ethos are given priority. This hierarchizing of categories can be seen in a number of persistent trends in religious studies scholarship: first, the tendency to emphasize the distinction between sacred and profane and, as a corollary of the separation of church and state, to compartmentalize religion as something distinct from culture; second, the tendency to define religion 
as a "belief system" and to give priority to categories such as faith, belief, doctrine, and theology while under-privileging the role of practice, ritual, and law; third, the tendency to give precedence to the individual over the community as the locus of religious life and consequently to give less emphasis to the social and cultural dimensions of religion; and, fourth, the tendency to define religious identity in terms that privilege universalism over particularism and hence reflect a missionizing model of religious tradition. While recent developments in the fields of ritual studies and cultural studies have provided important correctives to such tendencies, the Protestant legacy still lingers-albeit unconsciously—in the practices of many scholars of religion. ${ }^{18}$

\section{Protestant-Based Paradigm: Hierarchical Dichotomies}

sacred
belief
doctrine
individual
universalism
modernity
profane
practice
law
community
particularism
tradition

The Protestant subtext of the dominant paradigms provides the implicit standard against which other religious traditions are compared and evaluated. While perhaps appropriate for the study of some religious traditions, such paradigms, together with the hierarchical taxonomies they perpetuate, become straitjackets when applied to other traditions. One of the tasks of the comparative study of religion in this context is to test and critique the prevailing paradigms, expose their inadequacies, and generate a range of possible models to account for the multiplicity of religious traditions. The comparative study of Hindu and Jewish traditions in particular serves to illustrate how two of the world's major religious traditions defy the classificatory schemas associated with the prevailing Protestant-based paradigms. These traditions construct other categories and taxonomies that bring to light different sets of relationships, such as those between religion and culture, ethnic identity and religious adherence, observance and non-observance, and purity and impurity. Such relationships are 
obscured by the application of the prevailing models. In contrast to the Protestant-based paradigms, in which precedence is given to belief, doctrine, and theology, and tradition-identity is rooted in the universalizing values of missionizing traditions, Hindu and Jewish traditions provide alternative models of religious tradition, in which priority is given to issues of practice, observance, and law, and tradition-identity is defined primarily in terms of particular ethnic and cultural categories that are tied to notions of blood descent.

Among the array of Hinduisms and Judaisms, brāhmanical Hinduism and rabbinic Judaism in particular share significant affinities. Indeed, my work suggests that - contrary to the stereotypical characterization of Hindu and Jewish traditions as representing opposite ends of the spectrum of the world's religions - the brāhmanical and rabbinic traditions constitute two species of the same genus of religious tradition: as elite textual communities that have codified their respective norms in the form of scriptural canons; as ethno-cultural systems concerned with issues of family, ethnic and cultural integrity, blood lineages, and the intergenerational transmission of traditions; and as religions of orthopraxy characterized by hereditary priesthoods and sacrificial traditions, comprehensive legal systems, complex dietary laws, and elaborate regulations concerning purity and impurity. I term the brāhmanical and rabbinic traditions "embodied communities" in that their notions of traditionidentity, in contrast to the universalizing tendencies of missionizing traditions, are embodied in the particularities of ethnic and cultural categories defined in relation to a particular people (Indo-Āryans, Jews), a particular sacred language (Sanskrit, Hebrew), and a particular land (Āryāvarta, Israel). These ethno-cultural systems share an abiding concern for the body as a site of central significance that is the vehicle for the maintenance of the social, cosmic, and divine orders. The body is the instrument of biological and socio-cultural reproduction that is to be regulated through ritual and social duties, maintained in purity, sustained through proper diet, and reproduced through appropriate sexual relations. In their roles as "peoples of the body" traditions provide the basis for constructing alternative models of religious tradition to the prevailing Protestant-based paradigms. ${ }^{20}$

In order to ground this discussion of the "why" of comparative study in more practical considerations of "how" we might undertake the pro- 
posed type of comparative critical inquiry, I would like to reflect briefly on the work of the AAR Comparative Studies in Hinduisms and Judaisms Group (1998 to present), which I helped to establish along with its predecessor, the AAR Comparative Studies in Hinduisms and Judaisms Consultation (1995 to 1997). One of the express purposes of the Group, as well as of the Consultation on which it builds, has been to bring together specialists in South Asia and Judaica to engage in a series of sustained reflections on topics within Hinduisms and Judaisms, with the intention of challenging scholars of religion to critically reassess the dominant paradigms and to reconfigure our scholarly discourse to include a range of models and categories arising out of case studies of Hindu and Jewish traditions. The format for the sessions of the Comparative Studies in Hinduisms and Judaisms Group has generally included presentations by South Asian specialists and by Judaica specialists, followed by a response that serves to highlight the broader comparative implications of the presentations, especially with respect to their contributions to the revisioning of certain analytical categories in the study of religion. We have experimented with different formats, all of which are designed to foster collaborative research, including sessions with four complementary papers by specialists in the two traditions, sessions with two papers providing in-depth analyses of a particular theme, and sessions with a mix of comparative papers and joint presentations.

The program of sessions sponsored by the Comparative Studies in Hinduisms and Judaisms Group and Consultation since 1995 has engaged a wide spectrum of traditions in a diverse array of configurations: biblical and Vedic traditions, brāhmanical and rabbinic traditions, the esoteric traditions of Tantra and Kabbalah, bhakti and Hasidic movements, women's ritual traditions, modern nationalist movements in India and Israel, contemporary Hindu and Jewish diaspora communities, and so on. The sessions have explored new ways of thinking about certain analytical categories in the study of religion that are critical to our scholarly inquiries, such as constructions of purity and impurity (1995), regimens of domestic asceticism (1996), discourses of the body (1998), constructions of the female principle (1999), hermeneutical strategies (1999), genealogies of sacrifice (2000), the dialectic of homeland and diaspora (2001), religious nationalisms $(1997,2002)$, and meditation traditions (2003).

One example will have to suffice to illustrate the types of analytical 
categories and issues addressed by the Comparative Studies in Hinduisms and Judaisms Group and its predecessor, the Consultation. The two sessions of the Comparative Studies in Hinduisms and Judaisms Group in 2000 focused on a critical interrogation of prevailing theories of sacrifice in the academy, with particular emphasis on the ways in which Vedic and Jewish sacrificial traditions challenge the models of sacrifice proposed by theorists such as Henri Hubert and Marcel Mauss, René Girard, and Walter Burkert. ${ }^{21}$ One of the contributions of this comparative inquiry-particularly as represented in the work of scholars such as Kathryn McClymond $(2002,2008)$ who have undertaken sustained investigations of Vedic and Jewish sacrificial rituals - has been to call into question three assumptions that underlie the theories of Hubert and Mauss, Girard, Burkert, and others. The first assumption is that animal sacrifice is the paradigmatic form of sacrifice. The second assumption is that sacrifice involves the destruction of the offering — or the killing of the animal victim - and that the act of killing is the defining element of sacrifice. The third assumption, which follows from the first two, is that sacrifice can be equated with ritual violence. Ivan Strenski, in his review of studies of sacrifice in the 1990s, observes that "these days, the very concept of ritual violence seems to have been folded into that of sacrifice, making the two virtually identical.... This obsession with violence in studies of sacrifice shows little sign of diminishing" (1996: 11).

The initial phase of our comparative inquiry involves interrogating these three assumptions and demonstrating that theories that characterize sacrifice as ritual violence, which are based on Western exempla in which bloody animal sacrifices are paradigmatic, are inadequate to account for the Vedic sacrificial tradition. First, animal sacrifices are not paradigmatic in the Vedic case. The Vedic yajña, or "sacrifice," in its public form comprises the classical śrauta rituals that are traditionally divided into three principal classes, which are distinguished primarily by the material substances that are used as offerings or oblations: the iști, which centers on rice or barley offerings; the paśubandha, which is characterized by animal offerings; and the Soma ritual, which centers on offerings of juice from the Soma plant. It is the Soma ritual-not the paśubandha, or animal sacrifice-that is given precedence in the Vedic tradition as the paradigmatic sacrifice that is the apex of the sacrificial hierarchy. Second, the destruction of the offering is not the defining 
characteristic of śrauta sacrifice but rather must be understood as only one among a number of interdependent activities that together constitute the syntax of Vedic ritual. Third, the destruction of the offering is framed in classical Vedic ritual texts as part of a carefully ordered ritual system that relegates the messy actualities of violence and blood to the world beyond the ritual enclosure. ${ }^{22}$ In the case of the paśubandha, the destruction of the animal is characterized as "quietening" (root śam) and not as "killing" (root han), and the actual immolation is marginalized and domesticated in that it is performed outside the ritual enclosure and the animal is suffocated or strangled rather than decapitated, thus avoiding the inauspicious act of bloodletting. In the case of the Soma ritual, the paradigmatic Vedic sacrifice, the act of destruction involves the crushing and pressing of the Soma plant in order to extract the Soma juice that will be used as an oblation.

The first phase of our comparative inquiry thus leads to the conclusion that theories that imagine sacrifice as ritual violence involving the bloody slaying of a victim are not adequate to account for the multilayered significations of Vedic śrauta sacrifices. In the second phase of our inquiry we turn to the Jewish sacrificial tradition and attempt to reimagine sacrifice and open up hitherto unexplored dimensions by juxtaposing Jewish constructions of sacrifice with Vedic constructions. In the Jewish sacrificial tradition, in contrast to the Vedic tradition, animals are the preferred offering substance in four of the five classes of offerings delineated in biblical and rabbinic texts: the 'ōlāh ("burnt offering"), the hatțā't ("sin offering" or "purification offering"), the šs lāmîm ("peace offering" or "well-being offering"), and the 'āšăm ("guilt offering" or "transgression offering"). The fifth class of offerings comprises grain offerings, or minhāh.

As McClymond's work has emphasized, the investigation of Jewish sacrifice within a broader comparative framework that includes Vedic sacrifice brings to light a number of elements in the Jewish case that have previously received insufficient attention. First, vegetal offerings play a significant role in the Jewish sacrificial tradition, not only as a distinct class of offerings but also as an important component of animal sacrifices. Second, in the various classes of animal sacrifice, it is not the killing of the animal that is the defining element of the sacrifice, but it is rather the procedures for manipulating the blood and the methods of dividing and distributing the portions of the animal that distinguish one 
class of animal sacrifice from the other. As in the Vedic case, the destruction of the offering should be viewed not as the sine qua non of the sacrifice but rather as one among a number of interrelated activities that together constitute the sacrificial matrix. Third, the central importance of blood in the Jewish sacrificial tradition provides a counterpoint to the Vedic sacrificial tradition's abhorrence of blood. At the same time, if we shift our attention from the blood as a counterpart of the violent death of the animal to the blood as the "life-essence" of the animal, we open up fruitful avenues of comparative inquiry that point to the role of sacrifice in providing access to various types of life-essence: the blood that is extracted from the animal in Jewish animal sacrifices, the breath that is extracted from the animal in the Vedic paśubandha, and the juice that is extracted from the Soma plant in Vedic Soma rituals (see McClymond 2002, 2008).

This brief comparative venture into Vedic and Jewish constructions of sacrifice brings us back to a consideration of one of the important tasks of comparative study, which is to challenge scholars to critically interrogate the theories, models, and categories that serve to perpetuate the legacy of hegemonic paradigms in the academy-whether Eurocentric paradigms, Protestant Christian paradigms, or other dominant paradigms - and to reconstitute our scholarly discourse to allow for a multiplicity of epistemologies. Comparative analysis is not only intrinsic to the process through which categories and models are constructed and applied, but it also can serve as an important corrective to the discursive practices through which certain categories and models have been privileged over others in the human sciences. Comparative analysis can serve not only as a heuristic tool to establish taxonomies but also as a critical method to interrogate and dismantle their tyrannies. Understood in this way, comparative study is accorded its rightful place as a viable post-modern and post-postmodern approach that helps us to move beyond hegemony to multivocality, beyond tyranny to polyphony.

\section{Notes}

This article expands on my earlier reflections in Katz, Chakravarti, Sinha, and Weil 2007. 
1. In his use of the expression "Europeanization of the earth," Halbfass invokes both Husserl's discussion of the "Europeanization of all foreign parts of mankind" and Heidegger's reflections on the "complete Europeanization of the earth and of mankind" (see 1988: 167-70, 437, 439-42).

2. These two functions correspond, respectively, to the "heuristic" and "provocative" functions of comparison described by the comparative philosopher of religion Thomas Kasulis: "Comparison typically serves one of two purposes. It can, first of all, try to increase our understanding of one or both of the comparates by seeing one in light of the other. This is a heuristic function, a way of classifying and gathering information. Secondly, comparison may try to use the similarities and differences as a means of provoking a new perspective on a traditional issue.... This is a provocative function, one that leads immediately to questions, not answers" (1993: xiii).

3. This expression derives from Lincoln (1985).

4. This expression derives from Pollock (1993: 114-15).

5. Among representative works, see Abu-Lughod (1989); Blaut (1993, 2000); Chase-Dunn and Hall (1997); Chaudhuri (1990); Frank (1998); Frank and Gills (1993); Goody (1996); Hodgson (1993); Lewis and Wigen (1997); Perlin (1993, 1994); Pomeranz (2000); Sanderson (1995). The work of a number of these scholars will be discussed in the following analysis.

6. See in particular Blaut 1993, 2000.

7. For an articulation of this theory, see Jones 1981. Jones modified his position concerning European exceptionalism in his later 1988 work.

8. See also 30-41 for Blaut's discussion of the "ethnography of belief" and more specifically the Eurocentric belief system of the academic elite that served to foster the interests of European colonialism and neocolonialism.

9. This table is an adaptation and expansion of Blaut's table (17).

10. This expression derives from McNeill's (1963) classic study of world history.

11. See in particular Eaton's (1995) critique of Blaut's work (1993). See also Frank's (1998) critical reassessment of the work of Blaut and other world-system theorists, which will be discussed later.

12. For Abu-Lughod's overview of these eight subsystems, see 33-37.

13. In his co-edited volume with Gills (1993), Frank disputes Waller- 
stein's theory that the modern world-system that emerged in 1450 was the first and only world-system and argues instead that Wallerstein's five-hundred-year system is a continuation of the same world-system that has existed for at least five thousand years.

14. Cited in Delgado and Romero (2000: 11).

15. Goodman's introduction provides a brief survey of previous studies that have attempted to delineate connections between Hindu and Jewish traditions.

16. See also the special issue of Shofar on Judaism and Asian Religions edited by Kasimow (1999).

17. This analysis of AAR Program Units is based on data compiled from the AAR website, http://www.aarweb.org/Meetings/Annual_Meeting/ Program_Units/default.asp, in April 2010.

18. A number of scholars have raised issues concerning the persistence of Protestant presuppositions and categories in the academic study of religion (see, for example, Neusner 1986: 13-17; Schopen 1991). See also Staal's (1989: 387-419) more general critique of Western paradigms of religious tradition, which he argues are inappropriate for the study of Asian traditions.

19. Eilberg-Schwartz uses this designation for the Jews in his edited collection People of the Body: Jews and Judaism from an Embodied Perspective (1992). See also Boyarin 1993. For a brief analysis of Hindu discourses of the body, see Holdrege 1998. For an extended study, see Holdrege forthcoming.

20. Elsewhere I have suggested that one way of rethinking the notion of religious tradition is to posit a spectrum in which religious traditions are mapped according to different degrees of ethno-cultural specificity, with embodied communities such as brāhmanical Hinduism and rabbinic Judaism on one end of the spectrum and missionizing traditions such as Christian and Buddhist traditions on the other end. A range of intermediary cases could be mapped in between, such as the Islamic tradition, which constitutes a missionizing-yet-partially-embodied community (see Holdrege 1999, 1996). Morris (1992) has emphasized the heuristic value of positing two discrete models-missionary traditions (Christianities, Islams, Buddhisms) and non-missionary traditions (Hinduisms, Judaisms) - in order to elucidate the notion of religious tradition.

21. I am co-editing, along with Kathryn McClymond, a volume entitled 
Beyond Hubert and Mauss: Reimagining Sacrifice in Hindu and Jewish Traditions, which presents the collective fruits of the two sessions along with a number of additional essays.

22. Heesterman (1993), in his theory of Vedic ritual, posits a "preclassical" Indo-Āryan sacrifice that preceded the establishment of the "classical" Vedic śrauta ritual described in the Brāhmaṇas and Śrauta Sütras. He is particularly concerned to elucidate the mechanisms through which the "agonistic" pre-classical sacrifice, which was characterized by conflict, violence, and uncertainty, was transformed into the carefully regulated world of Vedic ritualism, which sought to establish an absolute order of perfect peace and stability within the ritual enclosure.

\section{References Cited}

Abu-Lughod, Janet L. 1989. Before European Hegemony: The World System A.D. 1250-1350. New York: Oxford University Press.

Abu-Lughod, Janet. 2001. "Middle East-Asian Connections: Before, During, and After European Hegemony." Paper delivered at the Symposium on the Middle East and South Asia: Comparative Perspectives, University of California, Santa Barbara.

Amin, Samir. 1989 [1988]. Eurocentrism (trans. Russell Moore). New York: Monthly Review Press.

Blaut, J.M. 1993. The Colonizer's Model of the World: Geographical Diffusionism and Eurocentric History. New York: Guilford Press.

Blaut, J.M. 2000. Eight Eurocentric Historians. New York: Guilford Press.

Boyarin, Daniel. 1993. Carnal Israel: Reading Sex in Talmudic Culture. Berkeley: University of California Press.

Breckenridge, Carol A., and Peter van der Veer. 1993. "Orientalism and the Postcolonial Predicament." In Carol A. Breckenridge and Peter van der Veer, eds., Orientalism and the Postcolonial Predicament: Perspectives on South Asia, 1-19. Philadelphia: University of Pennsylvania Press.

Chase-Dunn, Christopher, and Thomas D. Hall. 1997. Rise and Demise: Comparing World-Systems. Boulder: Westview Press.

Chaudhuri, K.N. 1990. Asia Before Europe: Economy and Civilisation of the Indian Ocean from the Rise of Islam to 1750. Cambridge: 
Cambridge University Press.

Delgado, L. Elena, and Rolando J. Romero. 2000. "Local Histories and Global Designs: An Interview with Walter Mignolo." Discourse 22, 3: 7-33.

Eaton, Richard M. 1995. Review of The Colonizer's Model of the World: Geographical Diffusionism and Eurocentric History, by J.M. Blaut. Contemporary Sociology 24, 3: 349-50.

Eilberg-Schwartz, Howard, ed. 1992. People of the Body: Jews and Judaism from an Embodied Perspective. Albany: State University of New York Press.

Frank, Andre Gunder. 1998. ReOrient: Global Economy in the Asian Age. Berkeley: University of California Press.

Frank, Andre Gunder and Barry K. Gills, eds. 1993. The World System: Five Hundred Years or Five Thousand? London: Routledge.

Goodman, Hananya, ed. 1994. Between Jerusalem and Benares: Comparative Studies in Judaism and Hinduism. Albany: State University of New York Press.

Goody, Jack. 1996. The East in the West. Cambridge: Cambridge University Press.

Halbfass, Wilhelm. 1988. India and Europe: An Essay in Understanding. Albany: State University of New York Press.

Heesterman, J.C. 1993. The Broken World of Sacrifice: An Essay in Ancient Indian Ritual. Chicago: University of Chicago Press.

Hodgson, Marshall G.S. 1993. Rethinking World History: Essays on Europe, Islam, and World History (ed. Edmund Burke III). Cambridge: Cambridge University Press.

Holdrege, Barbara A. 1996. Veda and Torah: Transcending the Textuality of Scripture. Albany: State University of New York Press.

Holdrege, Barbara A. 1998. "Body Connections: Hindu Discourses of the Body and the Study of Religion." International Journal of Hindu Studies 2, 3: 341-86.

Holdrege, Barbara A. 1999. "What Have Brahmins to Do with Rabbis? Embodied Communities and Paradigms of Religious Tradition." In Harold Kasimow, ed., Judaism and Asian Religions. Shofar 17, 3: $23-$ 50.

Holdrege, Barbara A. 2000. "What's Beyond the Post? Comparative Analysis as Critical Method." In Kimberley C. Patton and Benjamin C. 
Ray, eds., A Magic Still Dwells: Comparative Religion in the Postmodern Age, 77-91. Berkeley: University of California Press.

Holdrege, Barbara A. Forthcoming. The Body and the Self: Hindu Contributions to Theories of Embodiment.

Holdrege, Barbara A. and Kathryn McClymond, eds. Forthcoming. Beyond Hubert and Mauss: Reimagining Sacrifice in Hindu and Jewish Traditions.

Jones, E.L. 1981. The European Miracle: Environments, Economies, and Geopolitics in the History of Europe and Asia. Cambridge: Cambridge University Press.

Jones, E.L. 1988. Growth Recurring: Economic Change in World History. Oxford: Clarendon Press.

Kasimow, Harold, ed. 1999. Judaism and Asian Religions. Shofar 17, 3.

Kasulis, Thomas P. 1993. "Introduction.” In Thomas P. Kasulis, Roger T. Ames, and Wimal Dissanayake, eds., Self as Body in Asian Theory and Practice, xi-xxii. Albany: State University of New York Press.

Katz, Nathan, Ranabir Chakravarti, Braj M. Sinha, and Shalva Weil, eds. 2007. Indo-Judaic Studies in the Twenty-First Century: A View from the Margin. New York: Palgrave Macmillan.

Lewis, Martin W., and Kären E. Wigen, eds. 1997. The Myth of Continents: A Critique of Metageography. Berkeley: University of California Press.

Lincoln, Bruce. 1985. "The Tyranny of Taxonomy." Occasional Papers of the University of Minnesota Center for Humanistic Studies 1.

McClymond, Kathryn. 2002. "Death Be Not Proud: Reevaluating the Role of Killing in Sacrifice." International Journal of Hindu Studies 6, 3: $221-42$.

McClymond, Kathryn. 2008. Beyond Sacred Violence: A Comparative Study of Sacrifice. Baltimore: Johns Hopkins University Press.

McNeill, William H. 1963. The Rise of the West: A History of the Human Community. Chicago: University of Chicago Press.

Morris, Paul. 1992. "The Discourse of Traditions: 'Judaisms' and 'Hinduisms.' " Paper delivered at the Annual Meeting of the American Academy of Religion, San Francisco.

Neusner, Jacob. 1986. Ancient Judaism and Modern Category-Formation: "Judaism," "Midrash," "Messianism," and Canon in the Past Quarter-Century. Lanham: University Press of America. 
Perlin, Frank. 1993. The Invisible City: Monetary, Administrative and Popular Infrastructures in Asia and Europe, 1500-1900. Aldershot: Variorum.

Perlin, Frank. 1994. Unbroken Landscape: Commodity, Category, Sign and Identity; Their Production as Myth and Knowledge from 1500. Aldershot: Variorum.

Pollock, Sheldon. 1993. "Deep Orientalism? Notes on Sanskrit and Power Beyond the Raj." In Carol A. Breckenridge and Peter van der Veer, eds., Orientalism and the Postcolonial Predicament: Perspectives on South Asia, 76-133. Philadelphia: University of Pennsylvania Press.

Pomeranz, Kenneth. 2000. The Great Divergence: Europe, China, and the Making of the Modern World Economy. Princeton: Princeton University Press.

Reynolds, Dwight F. 2001. "The Middle East and South Asia: Comparative Perspectives." Project Prospectus, University of California, Santa Barbara.

Said, Edward W. 1978. Orientalism. New York: Vintage Books, Random House.

Sanderson, Stephen K., ed. 1995. Civilizations and World Systems: Studying World-Historical Change. Walnut Creek, Calif.: AltaMira Press, Sage Publications.

Schopen, Gregory. 1991. "Archaeology and Protestant Presuppositions in the Study of Indian Buddhism." History of Religions 31, 1: 1-23.

Staal, Frits. 1989. Rules without Meaning: Ritual, Mantras and the Human Sciences. New York: Peter Lang.

Strenski, Ivan. 1996. "Between Theory and Speciality: Sacrifice in the 90s," Religious Studies Review 22, 1: 10-20.

Wallerstein, Immanuel. 1974-89. The Modern World-System. 3 volumes. New York: Academic Press.

BARBARA A. HOLDREGE is Professor of Religious Studies (South Asian Traditions and Jewish Traditions) at the University of California, Santa Barbara.<holdrege@ religion.ucsb.edu>

Open Access This article is distributed under the terms of the Creative Commons Attribution Noncommercial License which permits any noncommercial use, distribution, and reproduction in any medium, provided the original author(s) and source are credited. 